\title{
A Psychological Reading of Husband-Wife Relationship in Death of a Salesman
}

\author{
XiaoChang ${ }^{1} \&$ Taehyung Kim $^{1}$ \\ ${ }^{1}$ Kunsan National University, Korea \\ Correspondence: Taehyung Kim, Kunsan National University, Korea. Tel: 82-63-469-4327. E-mail: feste11@ \\ hotmail.com, thkim11@kunsan.ac.kr
}

Received: September 30, 2021; Accepted: October 23, 2021; Published: October 24, 2021

\begin{abstract}
Death of a Salesman written by Arthur Miller premiered in 1949 to critical acclaim and commercial success. Scholars have been paying attention to research on the female characters, the protagonist from the psychological perspective and father-son relationship, none of these works deals with the husband-wife relationship in Death of a Salesman from a psychological aspect.The paper will examine the family competences of Linda and Willy, dissecting the husband-wife relationship combing the psychological motivation. In the first section, through psychological rejuvenation, Linda embodies a natural force of vigor that infuses in Willy the power of warmth. In the psychological interpretation of Death of a Salesman, the relationship between Willy and Linda formed a sharp contrast between psychological pressure and purifying salvation. Willy suffered from relational anxiety, fearful stress, repressive daily, the loss of body, which brought disaster to his wife, Linda, his sons, Biff and Happy. For this reason, the play arranged a comforting character, his wife, Linda, to contrast the relationship between the couple. Concerning the suppressive daily, Willy's stubborn personality is linked with frustration and depression in pursuing fantasy; his wife, Linda, gives him warm comfort for his empty dreams with her kindness, love, and above all, intelligence. In the case of his sons, Biff and Happy, especially Biff, on whom Willy places high expectations, Linda saved Willy from the relational tension through her pure nature when the sons frustrate Willy; Linda supports Willy and solves the arguments between Willy and sons to ease the tension. When Willy is faced with an unbearable blow from his job, Linda gives him advice on how to solve problems, such as when Willy loses his job, and the wife advises him to understand the boss and how to deal with the problem. The loneness from family and work also leads Willy to have affairs with an unknown woman; Linda tolerates everything and invisibly reminds Willy. It can be said that the relationship between the wife and her husband is a relationship of dependency, the wife attached to her husband in life and emotion.
\end{abstract}

Keywords: Husband-Wife Relationship, Death of a Salesman, Psychology, Attachment

\section{Introduction}

Death of a Salesman premiered in 1949 to critical acclaim and commercial success. The triumph of the work stems from how it depicts the social defects of capitalism and reflects the difficult life of a lower-class salesman living in the United States at that time, and how it directed the public's attention towards the reality of life for the lower classes. Death of a Salesman has been honored with the Pulitzer Prize, the Tony Award for Best Author, and the New York Drama Circle Critics' Award, confirming Arthur Miller as an international figure in literary circles.

Neil Carson claims that Willy Loman, the protagonist of Death of a Salesman, is a "universal symbol made real by hundreds of minutely observed details of speech, manner and psychology"(45), and consideration of Willy's personal life "has led many critics to approach the play as a psychological drama with strong Freudian colouring" (Neil Carson 49), one which particularly focuses on father-son conflicts. Carson suggests that Death of a Salesman can be studied from a psychological perspective.

Scholars have been inclined to explore the latent causes behind Willy's psychological breakdown. As Judith Wellek proposes, the "self-psychology principle" (213) is thought to govern one's deficits, shame, and probability of self-restoration, asserting that the conditions of birth and upbringing influence the maintenance of psychological equilibrium, and that guilt is a consequence of those conditions. His increasing consciousness of the shame that he bore finally brought about Loman's suicide. Wellek studies Willy's mental and emotional state from a psychological perspective, emphasizing the psychological causes behind Willy's suicide (213). 
American literary critic J. Hillis Miller put forward the literary interpretation theory, from the psychological, social, and linguistic perspectives. He specifically emphasizes that "Psychological explanations tend to see linguistic, religious, or social explanations as ultimately finding their cause in individual human psychology" (22). It is fascinating that the relationship between Linda and Willy can be regarded as a psychological game. Willy is a salesman at the bottom of the heap, doing precarious and low-paid work under a prolonged obsession with the American Dream. In such an average family, Willy, the central figure and the salesman of the title, has to rely on his low income to support his family of a wife and two sons, which to many people may seem inconceivable. Faced with a difficult life, Willy does not give up on his dream; his wish is to be linked with the ideology of bringing happiness to his family through his efforts, and he has placed high hopes on his children. It is also apparent that Willy, who is under a great deal of pressure, has the hope to keep living, and his reasons to continue lie in his traditional and understanding wife, Linda, and in his grand expectations for his sons.

Linda is "unconsciously motivated by a desire to maintain protective control over her husband ... [and she] suggests this control in her remark that she knows every thought in his mind" (Flanagan 131).This makes her an enigmatic character in the play, one good at observing her husband's states, grasping his mood, and understanding his needs, so she can take effective measures to help him understand the situation, mitigate his anxiety, and guide him in an invisible manner, which is all tied up in Linda's ability to empathize with Willy and "read his mind". Miller embarks on the journey of rejuvenation in Death of a Salesman through Linda, who never abandons Willy, using her understanding, gentleness, and wisdom to resolve conflicts when faced with Willy's sorrow of work pressure, emotional anxiety, and physical infirmity.

Regarding the relationship between husband and wife, Lily R. Gulrajani is perhaps one of the few scholars studying marital relationships. She discusses in The Family in the Plays how Willy is a "physically and mentally exhausted" (33) individual, disappointed with his relationships with his sons. Willy does his best to conceal this from Linda but Linda is not deceived, instead, she always pretends to save her husband's dignity (33). Gulrajani's research into the husband-wife relationship has gained ground in psychology, which has inspired me to further analyze Linda's efforts to maintain her husband.

As for the theory for conjugal relationship, Hampson \& Beavers $(1993,74)$ define family competence as the ability to finish "the necessary tasks of organizing and managing itself" in a family. Family competence includes a family's ability to communicate, cooperate, negotiate, position clear roles and goals, solve problems, take responsibility and so on (Beavers \& Hampson, 1990; Hampson \& Beavers, 1993, 1996).Family competence determines the familial relationship, including that between husband and wife. Accordingly, it is essential to assess family competence.

The paper will examine the family competences of Linda and Willy, dissecting the husband-wife relationship combing the psychological motivation. Thus, I intend to examine the family problems that arise in daily lives and work in an attempt to understand the psychological issues associated with the play, further exploring the characters' personalities, problem-solving skills and husband-wife roles in the family, with a focus on factors that have influence over marital satisfaction. In the first section, through psychological rejuvenation, Linda embodies a natural force of vigor that infuses in Willy the power of warmth.

\section{Repressive Daily Life vs. Warm Comfort}

The repressive life serves as an impetus behind changing one's life habits, attitudes, and behavior. In this case, Willy's desire to provide his wife with a comfortable life has been shattered by his inability to make his dream come true. He has overestimated his abilities, thus his failure to make a fortune has frustrated him, leading to his rude and sour attitude towards his wife.

Through the lines between Linda and Willy, it is clear to find Willy's rude and sour attitude in repressive daily life. In Act 1, Linda asks Willy solicitously about the trip experience by asking "What happened? Did something happen, Willy?" (12; act1), Willy responds in annoyance, "I said nothing happened. Didn't you hear me?" (13; act1). His impatience shows his disrespect to his wife, who is still consistently giving him support and tolerance. As their sons Biff and Happy talk about their plan of playing ball, Linda encourages them, "maybe things are beginning to [change]" (64; act1).

Willy feels annoyed by Linda's behavior and scolds her for interrupting their conversation by shouting "Stop interrupting" (64; act1), "will you stop" (64; act1), "will you let me talk" (65; act1). He even gets angry and curses at his wife, "god-dammit"(65; act1), regardless of her feelings. 
Confronted with her husband's anger for no reason, Linda keeps silent all the time. Linda's silence doesn't mean she won't respond. She loves Willy so much that she wants her reply to remind her husband in a gentle way, such as silence, and serve to help her husband.

When Willy comes back home, Linda cares for her husband with words of concern, for instance, "where were you all day? You look terrible" (14; act1), "you'll just have to take a rest, Willy, you can't continue this way" (14; act1). Not only does Linda care about Willy's emotional well-being at work, but she also takes good care of him in her daily life, "taking the jacket from him" (14; act1), "take an aspirin. Should I get you an aspirin? It'll soothe you" (14; act1), "I'll make you a sandwich" (15; act1). Through her words and behavior, Linda provides warmth to her husband.

The reason why Linda can provide warmth to her husband is because of her intelligence to help her husband in keeping a balance between life and work. Focusing intensely on Linda's intelligence, I reveal several clues that can support the argument of Linda's wisdom. When father and sons disagree with each other, and Willy feels hurt inside, Linda tries to persuade husband not to worry about sons too much and ease his mind by saying, "He'll find his way" (18). As an ancient Chinese saying goes, each one of your sons and your grandsons must find his way as he ought. This kind of instruction is great wisdom of life, and perhaps excessive attention will cause the opposite effect, so let nature take its course.

Miller relates that the second indication of Linda's intelligence was one firmly founded on Linda's intrinsic prescience that Willy would brag about making money—she understands Willy's nature under any circumstances.

WILLY: I did five hundred gross in Providence and seven hundred gross in Boston.

LINDA: No! Wait a minute, I've got a pencil. She pulls pencil

and paper out of her apron pocket. That makes your

commission... Two hundred- my God! Two hundred and twelve dollars!

WILLY: Well, I didn't figure it yet, but...

LINDA: How much did you do?

WILLY: Well, I-I did- about a hundred and eighty gross in

Providence. Well, no-itcame to-roughly two hundred gross on the whole trip.

LINDA, without hesitation: Two hundred gross. That's ... She figures. (35; act1)

Willy is deceiving her that the bill is more than 200 gross. However, when examined closely, Miller's motives regarding Willy's trickery seem decidedly at odds with his actual situation that the bill is only 180 gross, close to 200 gross, instead of 200. Additionally, Willy is ready to betray his conscience and professes that he could support providing more money. Linda pretends to believe Willy and takes out the pen from the apron pocket to write the figure, saying in surprise "That makes your commission... Two hundred-my God! Two hundred and twelve dollars!" (35; act1). Then she immediately brings Willy back to life by stating how much money he needs to buy a refrigerator at home, which is refused immediately by stingy Willy. It seems that Miller purposefully describe Linda's wisdom of seeing through her husband's lies, and bringing her husband back to reality, specifically designed to divert attention from helping him understand the situation correctly and, therefore, avoiding unrealistic boasts.

It is noteworthy that Miller was redirecting the publicity surrounding Willy's appearance before he feels an objection to the payment for the "washing machine" (36; act1), "vacuum cleaner" (36; act1), "roof" (36; act1). In order to prevent her husband from overly boasting and complacent, Linda reminds him that there is still a lot to spend in the family. Whatever his intention, Arthur Miller admits Linda's great emotional intelligence from teaching Willy to be an honest true man. So far, Linda is depicted as an endless instructor for Willy, asserting that Willy has to pay for the Chevrolet by saying, "Well, you owe him three and a half" (36; act1). Willy is reluctant to pay for the Chevrolet. He hesitates for fear that the business may fail to live up to his expectations and he would be laughed at by saying "A hundred and twenty dollars! My God, if business don't pick up I don't know what I'm gonna do!" (36; act1); as such, Linda is pacifying to Willy, claiming that "next week you'll do better" (36; act1) and comforting him by saying, "Why? Why would they laugh at you? Don't talk that way, Willy" (36; act1).

Interestingly, Miller provides the third proof of Linda's intelligence and keen insight, and he does so in a way that establishes a direct connection to Linda's ability to sense her husband's emotional state.

BIFF, at the peak of his fury: Pop, I'm nothing! I'm nothing, Pop. Can't you understand that? There's no spite in it any more. I'm just what I am, that's all. 
Biff's fury has spent itself, and he breaks down, sobbing, holding on to Willy, who dumbly fumbles for Biff's face.

Willy, astonished: What're you doing? What're you doing?

To Linda: Why is he crying?

$\cdots$

LINDA: He loves you, Willy!

$\cdots$

WILLY: Oh, Biff! Staring wildly: He cried! Cried to me. He is choking with his love, and now cries out his promise: That boy- that boy is going to bemagnificent!

$\cdots$

Linda, sensing the racing of his mind, fearfully, carefully: Now come to bed.

Willy. It's all settled now.(133; act2)

As in Act 2, Linda understands that Willy wants her son to admire him. When a father-son conflict arises, Linda resolves the father-son conflict by telling Willy that his son is crying because he loves his father Willy. So Linda cautiously and sacredly persuaded Willy to go back to the room and rest. There is a scene in Act 2, "Linda, sensing the racing of his mind, fearfully, carefully (133; act2)", which showcases that Linda's abilities of reading Willy's minds and reassuring Willy's worries were used by Miller to set the conflict between Willy and his sons regarding her perception after she found Willy has changed his mind. From this standpoint, in Miller's literature, Linda is primarily configured to a submissive, considerate, intelligent figure.

This couple loves each other deeply. To Linda, Willy is the hope of her life. Although Willy also loves his wife very much, his bad temper prevents him from treating Linda respectfully. It is Linda taking care of Willy so much that has made him be good for nothing, and even he can't perform daily work successfully in the repressive life without Linda's warm comforting words.

\section{Fearful Pressure vs. Emotional Soothing}

Miller adds to the description of Linda's healthy disposition while Willy works out of his weak heart and mind. Willy suffers from a fearful financial burden, and he has to work day and night to support his family and pay off loans. Willy's work pressure comes from two aspects: social anxiety and psychological stress. He is a man full of fantasy; on the one hand, he intends to change the status quo of his family through his efforts and achieve a successful life. On the other hand, the personality defects like blind arrogance and his fear of losing face cannot get him out of the plight of reality, and, accordingly, his failure is inevitable. Linda, a traditional wife, is dependent on Willy because she doesn't have a job. She understands Willy's struggles and cares about his work. But all she can do is to give him verbal attention and advice about work.

In Arthur Miller's description of economic insecurity, the dramatist depicts the economic inequality and competitive capitalist system in postwar society. In the late nineteenth century, the speech of "Acres of Diamonds" made by Russell Conwell emphasizes in 1986 that everyone has to get rich and urges people to pursue success in the business world (Carol Barber 3). In the beginning and middle twentieth century, most families are units that live for a better life. Death of a Salesman resonates with the society at that time, which is an essential reason for Willy's financial failure. Working for a lifetime as a salesman for the Howard family company, Willy is fired by Howard with a self-serving and cold-blooded look, which drives him over the edge and shatters his long-held belief that if you work hard, you can succeed. Linda is a wife with a healthy personality and a gentle disposition. Confronted with Willy's failure at work, Linda is always there for him, comforting him and giving him advice.

When Willy loses confidence and says "I'm fat. I'm very foolish to look at, Linda" (37; act1), "I won't take that. I simply will not take that. But they do laugh at me. I know that" (37; act1), Linda stays with him and consoles him. Willy's lack of confidence is reflected in his fear of being stupid and being laughed at. Whereas when he says, "I gotta overcome it" (37; act1), it reflects that he has not reconciled change, and there is a willingness to struggle with reality. Under such conditions, Linda can do nothing but to comfort and encourage him; "Willy, darling, you're the handsomest man in the world" (37; act1).

His assertions of self-confidence and boasting at random unveil his self-doubts and uncertainty. "You know, the trouble is, Linda, people don't seem to take to me ... I know it when I walk in. They seem to laugh at me" (36; act1). Even confronting financial crisis and unemployment, Willy's self-inferiority leads him to lack confidence in himself in the face of a successful businessman, Charley, and he pretends to be strong on the surface. Linda, 
who understands everything about Willy, affirmed her husband by complimenting him as "the handsomest man in the world" (37; act1) and by acclaiming to him that "few men are idolized by their children the way you are" (37; act1).In addition to comforting him, Linda makes excuses for Willy. In the last scene of Act 1, she makes excuses for him by explaining that Willy did not attempt to hurt her but wanted to be superior to somebody(Chavkin and Chavkin31)(Note 1). However, no matter how much Linda advised Willy at work, Willy always seemed to stick to his own set of principles, as he was interested in saving face.

Linda suggests Willy ask his boss, the junior Wagner, for help to find stable office work in New York. Nevertheless, Willy refused to do so because he doesn't want to lose his face and is very assertive about his job of a valuable salesman. Manocchio in Families Under Stress wrote about Willy's feelings under the pressure of losing his job:

When this happens to a man he must not only face himself but also his family. When a man is like Willy and a job is the central part of his life, this must be doubly horrifying because his degradation is so much more complete. And under the circumstances, the whole family becomes the victim. (135)

Linda is a wife with healthy morals and a sunny attitude toward life. Willy is opinionated and stubborn at work, he's self-conscious, and he has unrealistic dreams. Linda is there for Willy, to comfort and encourage him when he shows signs of depression at work. When Willy is too embarrassed to plead with his boss and is ready to give up, Linda is there to help her husband. In terms of work, it can be said that Linda influences her husband through her healthy instincts.

\section{Relational Anxiety vs. Purifying Salvation}

A deeper exploration of Willy's psychology will urge us to seek a third interpretation of his relational anxiety. Willy himself has suffered emotional pain since childhood. His experience of love loss when his father abandoned his family left an indelible mark in his inner heart. He still can't forget the painful memories. In order to enable his children not to replicate his childhood abandonment, Willy did his best to create conditions under which children can study, and still dreams about being a wealthy man, as his brother expected. In the play, there is a clue that can demonstrate the point; "Well, Dad left when I was such a baby, and I never had a chance to talk to him, and I still feel-kind of temporary about myself" (51; act1). The sentence "never had a chance to talk to him" expresses his nostalgia for his father and his regret for his unhappy childhood.

When Willy utters his "kind of temporary (51; act1)" feeling about himself, he expresses his inner despair and helplessness. According to Freud's psychology, the repressed experiences of childhood explode like landmines at the right time(Lewis45)(Note 2). Willy's unhappy childhood experience motivates him to create his son's lifechanging opportunities through his struggles in social life. However, his two sons, Biff and Happy, devastate his dreams, as they are reluctant to achieve his goal of pursuing a prosperous future. The tension of the father-son relationship in the Loman family can be reflected in Willy's treatment of his two sons, respectively. Although Biff shows both his own self-esteem and respect for his father, the fact that he is not as ambitious as his father expected, has no direction toward life, and is unable to keep any job for very long, demonstrates that contradiction might exist in the father-son relationship. Willy questions Biff, "You don't want to be anything, is that what's behind it?"(112; act2). Biff argues, "Don't take it that way! You think it was easy walking into that office after what I'd done to him? A team of horses couldn't have dragged me back to Bill Oliver!" (113; act2). The lost Biff steals the former employer Oliver's pen because he never thought of being a salesman for Oliver and tries to hide the facts of what happened in Oliver's office.

After Willy discovers that Biff's business dream turns out to be stealing the pen from his former boss, he feels frustrated and loses confidence in Biff. Finally losing control of his emotions, and unable to accept the fact that his son, Biff, who was expected to be the excellent, would fail senior-year math and commit such an immoral act of stealing Oliver's pen, Willy bursts out hysterically, "Don't blame everything on me! I didn't flunk math-you did! What pen"(110; act2). The most essential reason for their relational failure is that when Biff discovers Willy's affair with another woman, the great image of his father collapses. Biff is emotionally unable to accept the fact that his father is cheating, and Willy is also left with a heavy sense of shame. The relationship between Biff and Willy has become negative mainly because of Willy's agitated character and dominant behavior; What's more, Willy is a man without a mind of his own and without a proper understanding of the situation, whose love for his sons is out of balance, which causes the failure in father-sons relationship. Willy takes it for granted that it could be easier for his son Biff to be successful and is displeased at Biff's conduct of wasting time on the farm. At the beginning of the conversation in Act 1, Willy labels Biff "a lazy bum" (16; act1); later, Willy changed his description by depicting Biff as a "hard worker" (16; act1), which can demonstrate Willy's contradictory mind that may lead to the Biff's failure. 
Willy seldom pays attention to little son, Happy, is immature, irresponsible, and discontented with his expectations. Willy places high hopes on Biff and turns a blind eye to Happy when Happy says, "I'm losing weight, you notice, Pop" (29; act1). As the little brother, Happy cannot accept this kind of preference for Biff. He once said, "I bet he'd back you. Cause he thought highly of you, Biff" (26; act1). Eventually, this preference for Biff ends in an unstable relationship between Willy and Biff.

In the face of father-son tension, Linda is in between them and unable to back down or quit. As the tension between father and son grow, Linda, who stood by, worries that she wanted to protect her husband and not hurt her sons. To resolve the conflict between father and son, she has to do ideological work for them.

On the one hand, by pointing out Willy's problems in the father-sons relationship, grasping Willy's s emotional focus saves the father-sons relationship. Linda points out Willy's problem directly, for he is too critical of his son Biff, and reminds him, "You mustn't lose your temper with him" (15; act1). When Biff and Willy get into a fight, Biff cries; Willy asks Linda why he is crying. Linda knows Willy loves his children, so she comforts Willy by answering that Biff loves him. Willy cares more about his children than his wife. However, Linda cares more about Willy's feelings than her sons; she tries every trick to get Willy to calm down.

LINDA: No. You can't just come to see me, because I love him. With a threat, but only a threat, of tears: He's the dearest man in the world to me, and I won't have anyone making him feel unwanted and low and blue. You've got to make up your mind now, darling, there's no leeway any more. Either he's your father and you pay him that respect, or else you're not to come here. I know he's not easy to get along with-nobody knows that better than me- but ... (55; act1)

On the other hand, when Linda finds out that her sons did not respect their father, she reminds her sons, "Attention, attention must be finally paid to such a person" (56; act1) when the boys get home. Her extensive attention to Willy has spurred on her attempts at persuading her sons to overlook their father's weaknesses instead of comprehending their father and herself. Linda is worried that her sons are becoming indifferent to Willy, who will not accept that fact. Thus, she tries to lead her sons to believe and to love their father and save Willy from selfdestruction.

LINDA: He's the dearest man in the world to me, and I won't have anyone making him feel unwanted and low and blue. You've got to make up your mind now, darling, there's no leeway anymore. Either he's your father and you pay him that respect, or else you're not to come here. I know he's not easy to get along with- nobody knows that better than me- but ..." (55; act1).

When the Loman brothers come back home, Linda scolds the boys for abandoning their father at the Frank's Chop House. Linda's criticism urges Happy to go out and search for his father.

LINDA: (her voice subdued). What'd you have to start that for? (Biff turns away.) You see how sweet he was as soon as you talked hopefully? (She goes over to Biff.) Come up and say good night to him. Don't let him go to bed that way (65; act1).

However, no matter how hard Linda tries, the unpleasant father-son issues make Willy escape from reality and indulge in the fantasy that his sons are washing his car under a pleasant atmosphere. The flute music in the play also serves as a reminder that brings Willy's past and present together. Whenever life becomes stressful for him, music marks that Willy goes back to the past as "a single trumpet note jars the ear" (109; act2), and begins his fantasy dream. According to Willy, his little son Happy's complaint about his father's disrespectful and demeaning manner toward Linda binds Willy over to scream out his regret about not doing business with Ben in Alaska.

When it comes to family relationships, Linda has always been there for her husband, defending him and resolving conflicts between husband and sons. Of particular importance is this pattern in the relationship between Linda and Willy, for that comforting relationship has stabilized the Loman family cohesion.

\section{The Loss of Body vs Invisible Reminder}

As I mentioned before, a plausible explanation for Willy's madness could also be found in his infidelity. Faced with the tension of a father-son relationship, the pressure of a painful job, and the pressure of a heavy life, Willy often feels empty and lonely. Willy's work usually requires him to change places and conditions, sacrificing time with family. Willy often drives alone from Brooklyn to another area of the country. Willy is tired of the lonely life. To ease his loneliness, he forgets his family, temporarily loses himself, and has an affair with an unknown woman. Despite Linda's efforts to keep the family together, she cannot get Willy out of his shell. Willy has an affair with the unknown lady, not only because of sex, but also because the unknown lady can fulfill the need of getting rid of loneliness in a way that Linda cannot. When Biff discovers Willy having an extramarital affair, Willy tries to 
excuse his behavior by explaining, "She is nothing to me, Biff. I was lonely, I was terribly lonely" (120; act2). Willy's fear of abandonment is derived from his fear of loneliness.

The word "whore" being mentioned by Linda, as when Biff is faced with the unknown lady and he calls her a "whore"(31) in the notebook, implies that those plots are not coincidence. The subtle use of these changes is intended to imply that Linda was aware of her husband's infidelity.

The playwright repeatedly mentions the laughter from the woman. "Off left, the woman laughs" $(113,115$; act2) is mentioned twice. This gives expression to Willy's guilty conscience with regard to Linda. The repeated mentioning of stockings is a symbol of betrayal and sexual infidelity. Miller's repeated mentions of the frequent laughter and silk stockings are no coincidence. The playwright refers to them deliberately, partly to express Willy's guilt and discomfort after the affair. Later Willy says "You're the best there is, Linda, you're a pal, you know that? On the road - on the road I want to grab you sometimes and just kiss the life outa you"(38; act1), which also demonstrates Willy's uneasy psychology.

The Woman bursts out laughing, and Linda's laughter blends in. The Woman disappears into the dark. Now the area at the kitchen table brightens. Linda is sitting where she was at the kitchen table, but now is mending a pair of her silk stockings.

Linda: You are, Willy. The handsomest man. You've got no reason to feel that-

Willy, coming out of The Woman's dimming area and going over to Linda: I'll make it all up to you, Linda, I'll -

Linda: There's nothing to make up, dear. You're doing fine, better than-

Willy, noticing her mending: What's that?

Linda: Just mending my stockings. They're so expensive-

Willy, angrily, taking them from her: I won't have you mending stockings in this house! Now throw them out!

Linda puts the stockings in her pocket. (39; act1)

The playwright mentions the laughter twice, as well as Willy's unnatural behavior, which indicates that Willy is afraid of losing his wife because of his extramarital mistakes. On the other hand, the playwright is trying to emphasize that Linda already knows about her husband's affair, and she has no choice but to use this invisible way, sewing silk stockings, to remind her husband of what he's done. Two clues can indicate Linda's detection of her husband's extramarital affair.

Linda is intelligent, as I mentioned in the discussion of their daily life. Thus, Willy's abnormal behavior could not have gone unnoticed by Linda, especially when she is mending her stockings. Willy begins to feel apprehensive and cowardly. He nonsensically criticizes her, "will you stop mending stockings? At least while I'm in the house. It gets me nervous. I can't tell you. Please" (75; act2). Willy mentions that Linda ought not to sew silk stockings in the house, stressed that making silk stockings made him nervous, and he could not reveal why she was not allowed to sew them in front of Willy. It is impossible to avoid Linda's suspicion in light of Willy's erratic behavior, and the intelligent, insightful Linda is certainly aware of her husband's abnormal behavior.

The playwright mentions the unknown woman with silk stockings twice, and Linda sews silk stockings twice, which is the second clue to indicate Linda's detection of her husbands' affair with another woman. In Act 1, when Linda is sewing the silk stockings for the first time, Willy gets very angry and takes socks from Linda. "There is a dramatic irony in the stockings which Linda mends as contrasted with the stockings Willy gives to the woman in the Boston hotel, and the stockings become a symbol for Willy's guilt—guilt towards wife and son" (Carol Barber 48).

In Act 2, when he sees Linda sewing for the second time, Willy expresses the reason why he doesn't want Linda to mend stockings, but he doesn't mention the real cause of his anxieties.

She kisses him, and a silk stocking is seen hanging from her hand. Willy notices it.

Willy: Willy you stop mending stockings? At least while I'm in the house. It gets me nervous. I can't tell you. Please.

Linda hides the stocking in her hand as she follows Willy across the forestage in front of the house. (75; act2) 
All of these references are intended to suggest Willy's fear of being found out by his wife and his guilty conscience. Ronald J. Burke and Tamara Weir proposed that "females are better able to respond to non-verbal communication cues than are males. Perhaps it is this sensitivity which permits wives to recognize the emotional state of their spouses and to initiate a helping interaction more readily when needed" (62). Linda has no right to speech, and perhaps a casual remark would have provoked Willy or maybe led to Willy's downfall. Linda keeps her husband in the dark, showing due respect for his feelings, doing what he wants, and when he tells her to stop sewing, she stops sewing. Following common sense, with Linda's wisdom and insight, knowing that her husband doesn't like how she behaves, she may stop immediately. But Linda also does things that displease her husband, as she is sewing silk stockings for the second time; it is apparent that Linda is trying to remind her husband invisibly and express her unhappiness.

Faced with her husband's physical infidelity, Linda did not complain or blame. She chose to preserve her husband's dignity in a silent way. At the same time, she gave her husband a silent reminder by mending stockings many times. It is evident that Willy holds the dominant power of the family and that he has always been strong-willed and quick-tempered in family matters; as he is ostensibly strong, but emasculate in his inner world. There is no doubt that such a wise, caring, and affectionate wife has become an umbrella for his fragile soul.

\section{The Psychological Implication of Husband-Wife Relationship}

According to Freud's psychology, the repressed experiences of childhood explode like landmines at the right time(Note 2). Willy's miserable childhood without father and mother, left him with a traumatic experience. With this background, in the face of many disappointments in life, he decides to commit suicide.

The dominant husband-wife relationship demonstrates the reconciliation that makes with familial continuity through the wife and the recognition of the healing powers of the wife. This kind of reconciliation can be reflected from the perspectives of personalities, problem-solving skills and husband-wife roles.

Regarding the personalities, through the lines between Linda and Willy, it is clear that Willy is an emotionally unstable person with sour attitude. Willy feels annoyed by Linda's behavior and scolds her for interrupting their conversation by shouting "Stop interrupting" (64; act1) etc. As Leber, B. Douglas notes, "Feelings of nervousness, tension, and worry, as well as anger, self-dissatisfaction, and guilt characterize persons with low emotional stability" (Leber, B. Douglas 12), and we find such clues that Willy is a person with low emotional stability.

In contrast with her husband's personality, Linda is an emotionally stable person who seldom gets angry easily even if some things that seem unacceptable to ordinary people happen, such as the husband's yelling at her, the husband deprives her of the right to speak. According to B. Douglas Leber, "emotionally stable persons display contentment, security, and self-satisfaction" (12).We can read the emotional security sense from Linda, she always gives her husband a sense of security emotionally. Linda's tries to please Willy in an emotionally stable way because she cares for her husband very much. Linda intends to protect Willy and puts him in a fantasy world at the same time because she loves him and worries that he is on the verge of being lost. Linda uses her sympathetic, dependable emotions to care for Willy, who tends to be more hostile and demanding. Linda always stands by and clings to her husband even though she has no discourse power.

Beginning with the description, "Linda, his wife, has stirred in her bed at the right. She gets out and puts on a robe, listening. Most often jovial, she has developed iron repression of her exceptions to Willy's behavior-She more than loves him, she admires him, as though his mercurial nature, his temper, his massive dreams, and little cruelties, served her only as sharp reminders of the turbulent longings within him, longings which she shares but lacks the temperament to utter and follow to their end" $(12$; act 1$)$. The description at the beginning of the article also demonstrates the sense of security Linda gives Willy through love.

When Willy comes back home, feels exhausted and shouted at her in his daily life, Linda is not affected by her husband's emotions, instead, she cares for her husband with words of concern, for instance, "where were you all day? You look terrible" (14; act1), Linda's stable emotions prompted her to provide her husband with a sense of security, and the reason she can provide a sense of security also comes from her wisdom to help her husband balance work and life and to give warmth.

Willy is not only unstable emotionally, but also very stubborn. Willy is also a stubborn person and never tries to adapt to social trends. This can be reflected on when Linda changes his cheese, he suddenly chimes in with his own opinion; "I don't want a change! I want Swiss cheese" (17; act1). When the couple argue with each other, Willy never thinks of making a compromise. Willy only allows people to be obedient to him. When Bernard reminds Willy that Biff will flunk math, Linda shows her agreement; this enrages Willy; "there's nothing the 
matter with him! You want him to be a wormlike Bernard? He's got spirit, personality" (40; act1). Linda is overwhelmed by grief and "almost in tears, exits into the living room" (40; act1).

According to this description of Willy and Linda, the play unveils the personalities of the protagonist and his wife. There is no doubt that Linda, who is angelic, industrious, kind, gentle, selfless, and loving, is the quintessential good wife with stable emotion. She has no needs of her own and is willing to sacrifice herself to her husband and family. As the description at the beginning of the play outlines, most of the time, she is pleasant; She not only has affection for him, but she also admires him and often praises him by saying, "Willy, you're the handsomest man in the world" (37; act1).

Although Willy is bad-tempered, unstable emotionally and stubborn sometimes, he loves Linda profoundly and wholeheartedly, but he is doubtful about Linda's feelings for him and hopes Linda can care about him by asking "you're not worried about me, are you, sweetheart?" (18; act1). However, he has made some mistakes and he's quite sure he cannot live without Linda, so he once expressed, "you're my foundation and my support, Linda" (18; act1).Thus, Willy is in charge of making money, whereas Linda is the one who ties the family together by giving warmth to Willy in their daily lives.

In addition to the personality as an important factor affecting marital relationship, problem-solving skill is also core factor that reflect the relationship between husband and wife. Willy's love for his wife and his wish to provide a comfortable life for her is unwavering and his aspiration for success is not under his control, and desperation and repression fill Willy's heart. He loves her but treats her poorly. In their family, Willy is the center, and Linda's obedience to Willy gives him unlimited support for his empty dreams, yet she is still dedicated to the family. It is a pity that she does not get due respect. Willy's response to Linda demonstrates his negative problem-solving skills, including complaining, criticizing, and other negative behaviors. Willy's frequent complaining about life and criticism of Linda directly implies that he lacks problem-solving skills. Positive problem-solving skills refer to direct expressions of feelings, offering constructive solutions, positive feedback, understanding with the partner (Johnson, M. D.; Cohan, C. L.; Davila, J.; Lawrence, E.; Rogge, R. D.; Karney, B. R.; Sullivan, K. T., \& Bradbury, T. N. 15-27). If the couple can communicate patiently in a positive way in life, the husband can fully consider the wife's position and feelings, and the wife can give husband constructive advice, the relationship between the couple will be in a virtuous cycle.

Linda represents the emotional core of the family with her realistic and tough character, as she masters positive problem-solving skills. She admires and supports Willy, solving the arguments between Willy and their sons to ease the tension. When Willy is confused at work, Linda suggests that he go to his boss to express his hope to continue his work or ask his boss to consider changing his work environment. In everyday life, Linda also encourages and takes care of Willy through behavior and language.

As I continue to find, "A wife's ability to use a 'soft start-up' approach when delivering criticism was predicted to be related to her husband's marital satisfaction" (Olsen 62), Linda is a wife who is good at using "soft start-up" to assist and comfort husband. Research also emphasizes that "a husband's ability to empathize with his wife during the problem-solving discussions was predicted to relate to his wife's marital satisfaction" (Olsen 62). Although Willy is not good at mastering problem-solving skills, he has the ability to feel his wife's emotional empathy, to feel his wife's anger, sadness and timely feedback, and to express his concern and love for his wife. Especially after Willy has an affair, his guilt makes him anxious, and he is abnormally anxious to express his love for his wife.

From the perspective of role analysis, "Civil law defines the husband role as that of the provider, and as having the supreme authority on the family as a unit"(Solar Urbiztondo53) (Note 3); religious law is also relevant to that concept, as "the man is the head of the household and makes decisions, a good wife takes care of the house and obeys"(Fernandez-Mendez16-17)(Note 4). This family is a dominant family with the characteristics of husbandprovider and wife-homemaker; the husband is responsible for earning money supporting the family, while the wife is responsible for taking care of the children and does housework at home.

In traditional society such as early 20th century America, the responsibility of a wife is assumed to take care of their children, their husband, and their home, while the husband is supposed to provide financial support. Linda not only performs the traditional duties of a wife, she unconditionally backs her husband, but also puts lifelong attention on the relationship between Willy and their sons, though she disregards her sons and reproves them by shouting, "get out of here, both of you, and don't come back, I don't want you tormenting him anymore" (124; act2) when she detects her sons' behavior may hurt Willy.

In relieving the husband's pressure, the wife always trusts her husband, and the husband and wife are emotionally dependent on each other. Ronald J. Burke and Tamara Weir mention, "An effective husband-wife helping 
relationship was characterized by greater self-disclosure, trust, mutual reliance, a larger repertoire of potentially helpful behaviors" (62). Linda and Willy rely on each other in daily life and trust each other because they share ideas and care about each other. It can be said that the relationship between the wife and her husband is a relationship of dependency and trust; the couple are attached in life and emotion. Especially, Linda is there for Willy, for giving him warm comfort, purifying salvation, emotional soothing, and an invisible reminder for Willy's affair with an unknown lady. Linda's support and help for Willy were practical to some extent.

However, in the end, Willy chooses suicide, which doesn't mean Linda's support for Willy was ineffective. Studies have shown that "Severe life pressures result in both husbands and wives feeling less effective as helpers to their spouses"(Ronald J. Burke and Tamara Weir 62), when couples face serious problems, "they may yield to feelings of helplessness and find it difficult to support or encourage one another through the adversities" (Ronald J. Burke and Tamara Weir 62). Tuttle describes Willy as "Miller's strongest example of the centrality of work in life ... Losing his job - the labor by which he defined himself-is the single event which precipitates his suicide" (10). Even if Linda is a wife close to the perfect image, she also failed to prevent her husband from committing suicide.

In the marriage life between Willy and Linda, Willy, as the husband, is the only breadwinner in the family, a salesman who lives at the bottom of society and not only earns a small income, but also faces the pressure of debt and losing his job. Faced with a depressing daily life, failed career, and a strained father-son relationship, Linda comforts Willy with warm words and enlightens him with a positive attitude to life. Even if Willy cheats, Linda not only doesn't leave him, but chooses to tolerate him and reminds him to return to the family. Even when Willy chooses to commit suicide, Linda is still doing everything in her power to stop Willy from doing so. Linda is always attached to Willy as a perfect wife role in traditional sense.

\section{Notes on Contributor}

First author: XiaoChang is an associate professor at Changsha Normal University, China. She is also a doctoral student in Kunsan National University, Korea majoring drama.

Corresponding author: Taehyung Kim is an assistant professor in Kunsan National University, Republic of Korea. He earned a Ph. D. at University of California at Irvine. His research interests include theatre, film, and popular culture.

\section{References}

Barber, C. M. (2002). Work and Family in Arthur Miller's Death of a Salesman (Published doctoral dissertation). California State University.

Burke, R. J., \& Tamara, W. (1975) The Husband-wife Relationship: How Significant in Career and Life Success? Business Quarterly, 40(3), 62.

Carson, N. (1982). Arthur Miller. London and Basingstoke: The Macmillan Press LTD. https://doi.org/10.1007/978-1-349-16735-7

Flanagan, J. K. (1969). Arthur Miller: A Study in Sources and Themes (Published doctoral dissertation). University of Notre Dame.

Gulrajani, L. R. (1978). The Family in the Plays of Arthur Miller(Published doctoral dissertation). McGill University.

Hampson, R. B., W. R., \& Hulgus, Y. (1990). Cross-Ethnic Family Differences: Interactional Assessment of White, Black, and Mexican-American Families. Journal of Marital and Family Therapy, 16, 307-319. https://doi.org/10.1111/j.1752-0606.1990.tb00852.x

Hampson, R. B., \& Beavers, W. R. (Ed.) (1993). Measuring Family Competence: The Beavers Systems Model. Froma Walsh, Normal Family Processes. New York: The Guilford Press. pp.73-103.

Hampson, R. B., \& Beavers, W. R. (1996a). Family Therapy and Outcome: Relationship between Therapist and Family Styles. Contemporary Family Therapy, 18, 347-360. https://doi.org/10.1007/BF02197047

Hampson, R. B., \& Beavers, W. R. (1996b). Measuring Family Therapy Outcome in a Clinical Setting: Families that Do Better or Do Worse in Therapy. Family Process, 35, 347-361.https://doi.org/10.1111/j.15455300.1996.00347.x

Johnson, M. D., Cohan, C. L., Davila, J., Lawrence, E., Rogge, R. D., Karney, B. R., Sullivan, K. T., \& Bradbury, T. N. (2005). Problem Solving Skills and Affective Expression as Predictors of Marital Change. Journal of Consulting and Clinical Psychology, 71, 15-27. https://doi.org/10.1037/0022-006X.73.1.15

Leber, B. Douglas. (1991). Perceptions of Marital Interaction as Mediators of Personality Effects on Marital 
Satisfaction(Published doctoral dissertation). The University of Michigan.

Manocchio, T., \& William, P. (1975). Families Under Stress: A Psychological Interpretation. London: Routledge.pp.135.

Miller, A. (1949). Death of a Salesman. Georgia, United States: The Murray Printing Company.

Miller, J. H. (Eds.). (1985). The Search for Grounds in Literary Study. Rhetoric and Form: Deconstruction at Yale. Robern Con Davis and Ronald Schleifer. Norman. pp. 22.

Olsen, N. (2006). Emotion Skills, Problem-Solving, and Marital Satisfaction: Investigating the Mediating Effect of Emotion Skills on the Relationship between Problem-Solving Skills and Marital Satisfaction (Published doctoral dissertation). Clark University.

Tuttle, J. (1996). The Efficacy of Work: Arthur Miller and Robert Camus. "The Myth of Sisyphus." American Drama., 5, 61-72.

Wellek, J. S. (1993). Kohut's Tragic Man: An Example from "Death of a Salesman”. Clinical Social Work Journal, 21(2), 213. https://doi.org/10.1007/BF00754535

\section{Notes}

Note 1. Allan Chavkin and Nancy FeylChavkin. (2015). Looking at Arthur Miller's Death of a Salesman through the Lens of Interpersonal Acceptance and Rejection Theory and Family Systems Theory. The Arthur Miller Journal, (10), 31.

Note 2. Lewis, H. B. (1983) ."Freud and Modern Psychology." The Emotional Basis of Human Behavior, (2), 45. Note 3. Solar Urbiztondo, Ursula. (1975). Cross-cultural Familial Relationships in American Novels and Plays:Assigned in the Freshman Reading Program at the University of Puerto Rico from 1969-1970. (Published doctoral dissertation). New York University.

Note 4. Fernandez-Mendez, "Familia Contemporanea De Hoy", pp. 16-17. (Quoted from

SolarUrbiztondo,Ursula. (1975). Cross-cultural Familial Relationships in American Novels and Plays: Assigned in the Freshman Reading Program at the University of Puerto Rico from 1969-1970. (Published doctoral dissertation) New York University, pp. 53-54.)

\section{Copyrights}

Copyright for this article is retained by the author(s), with first publication rights granted to the journal.

This is an open-access article distributed under the terms and conditions of the Creative Commons Attribution license (http://creativecommons.org/licenses/by/4.0/). 